University of Nebraska - Lincoln DigitalCommons@University of Nebraska - Lincoln

US Army Research

U.S. Department of Defense

2007

Role of U.S. military research programs in the development of U.S.-licensed vaccines for naturally occurring infectious diseases

Lynn W. Kitchen

Military Infectious Diseases Research Program, U.S. Army Medical Research and Materiel Command, Fort Detrick, MD, lynn.kitchen@us.army.mil

Follow this and additional works at: http://digitalcommons.unl.edu/usarmyresearch

Kitchen, Lynn W., "Role of U.S. military research programs in the development of U.S.-licensed vaccines for naturally occurring infectious diseases" (2007). US Army Research. 334.

http://digitalcommons.unl.edu/usarmyresearch/334

This Article is brought to you for free and open access by the U.S. Department of Defense at DigitalCommons@University of Nebraska - Lincoln. It has been accepted for inclusion in US Army Research by an authorized administrator of DigitalCommons@University of Nebraska - Lincoln. 
Review

\title{
Role of U.S. military research programs in the development of U.S.-licensed vaccines for naturally occurring infectious diseases ${ }^{\text {is }}$
}

\author{
Lynn W. Kitchen*, David W. Vaughn ${ }^{1}$ \\ Military Infectious Diseases Research Program, U.S. Army Medical Research and Materiel Command, \\ Fort Detrick, MD 21702-5012, USA
}

Received 29 November 2006; received in revised form 16 May 2007; accepted 19 July 2007

Available online 6 August 2007

\begin{abstract}
U.S. military physicians and researchers have collaborated in the development of eight U.S.-licensed vaccines since 1934, when product efficacy requirements were added to product safety requirements mandated in 1902. These vaccines include influenza (1945), rubella (1969), adenovirus types 4 and 7 (1980), meningococcus A, C, Y, W-135 (1981), hepatitis B (1981), oral typhoid (1989), Japanese encephalitis (1992), and hepatitis A (1995). Current efforts include new adenovirus and Japanese encephalitis vaccines, and vaccines to prevent dengue, diarrhea due to enterotoxigenic E. coli, Campylobacter, and Shigella, malaria, hemorrhagic fever with renal syndrome, scrub typhus, meningococcus type B, and HIV infection. All vaccines currently administered to U.S. military forces must be licensed by the U.S. Food and Drug Administration (FDA).
\end{abstract}

Published by Elsevier Ltd.

Keywords: Vaccines; U.S. military; U.S. FDA

\section{Contents}

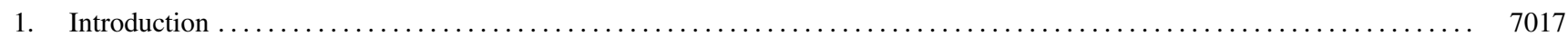

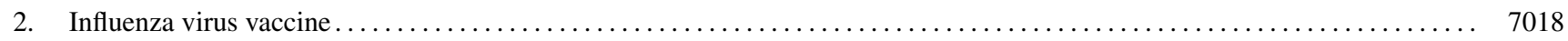

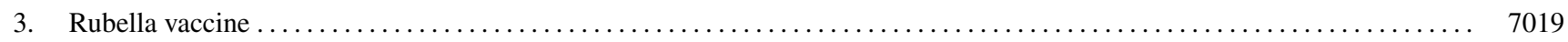

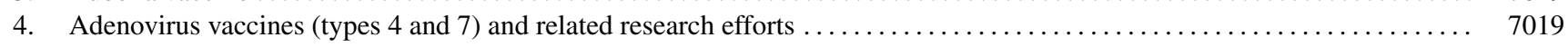

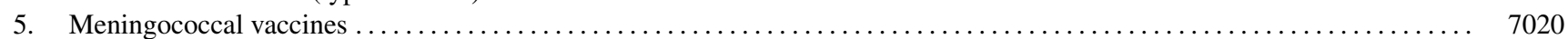

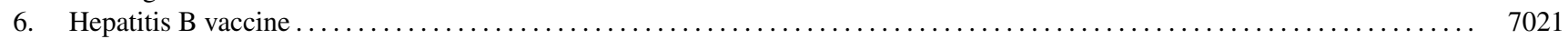

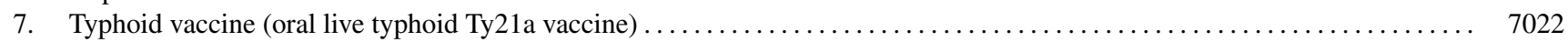

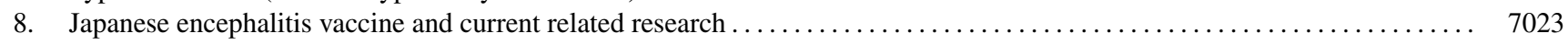

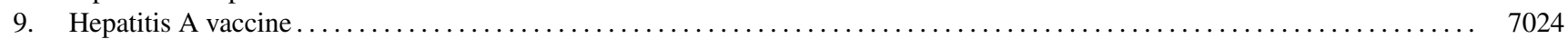

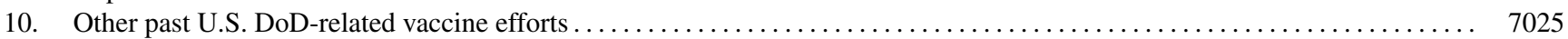

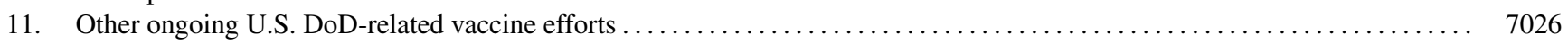

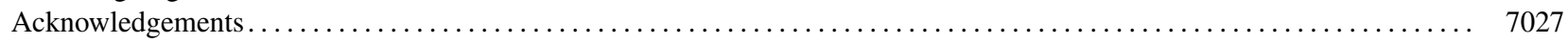

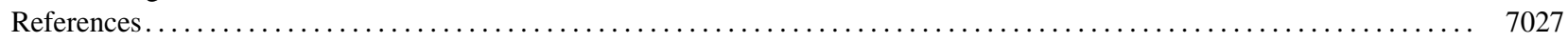

is The views expressed in this paper are those of the authors and do not reflect the official policy of the Department of the Army, Department of Defense, or the U.S. government.

* Corresponding author. Tel.: +1 301619 7560; fax: +1 3016192416.

E-mail address: Lynn.Kitchen@us.army.mil (L.W. Kitchen).

1 Current address: GlaxoSmithKline, King of Prussia, PA 19406-2772, USA.

\section{Introduction}

Development of vaccines for the U.S. military has been a priority for the U.S. Department of Defense (DoD) (and before it the Department of War (1789-1947) and the National Military Establishment (1947-1949)) because vaccines can be administered prior to deployment to protect 
service members from endemic diseases, thereby providing protection from infection while avoiding a logistical burden in the field. The U.S. military contributed to the development of approximately one-half of nonpediatric vaccines that are currently administered to service members at the time of induction or pre-deployment.

U.S. biologic safety regulation efforts commenced in 1902 with passage of the Biologics Control Act, following the deaths of 13 children in 1901 attributed to tetanus infections contracted via administration of diphtheria antitoxin generated by a tetanus-infected horse. U.S. biologics regulation was initially delegated to the Division of Pathology and Bacteriology within the Hygienic Laboratory of the Public Health and Marine Hospital Service. The Hygienic Laboratory was renamed the National Institute of Health (NIH, originally one institute) in 1930, and vaccine efficacy requirements were mandated in 1934. In 1937, regulatory biologics work was delegated to a newly established Division of Biologics Control within NIH. In 1944, this division was redesignated the Laboratory of Biologics Control, and in 1948 this division became part of the National Microbiological Institute. In 1955 this laboratory was given separate division status within the National Institutes of Health and renamed the Division of Biologics Standards. In 1972, responsibility for biologics regulation was shifted to the U.S. Food and Drug Administration (FDA), but many buildings where the biologic regulatory work is undertaken remain to this day on the NIH campus $[1,2]$. All vaccines currently administered to U.S. military forces must be U.S. FDA-licensed.

\section{Influenza virus vaccine}

The first U.S.-licensed vaccine co-developed by the U.S. military was an influenza virus vaccine. This vaccine was developed to protect service members and civilians from sickness and death due to influenza. During the influenza pandemic of 1918-1919, one out of every 67 U.S. service members died of influenza (mostly within a 10 -week period beginning in September 1918). The U.S. Army lost a greater proportion of men to death by disease in 1918 than in any year since 1867, when more than 43,000 U.S. sailors and soldiers died of flu and pneumonia. Furthermore, the close quartering and transport of large numbers of military personnel across oceans may have contributed to rapid global spread of influenza [3,4].

Influenza viruses are comprised of seven to eight singlestranded RNA gene segments. The segmented nature of the genome permits reassortment of RNA between influenza viruses during dual infection, thereby allowing the creation of forms of influenza unrecognized by the human immune system. The major reservoir for influenza $\mathrm{A}$ in nature is aquatic fowl, although swine are susceptible to infection with influenza viruses from both birds and humans and may serve as a "mixing vessel" resulting in novel, disease-causing strains. Influenza A and B viruses are the principal causes of epidemic influenza, although other respiratory viruses (including adenoviruses) can cause similar disease. Generalized symptoms, including fever, chills, muscle aches, and headaches generally precede other symptoms including sore throat, nasal symptoms, hoarseness, cough, and diarrhea. Death (in $0.1 \%$ of cases in most years) is generally limited to very young and very old persons, and is frequently attributed to pneumonia. In the 1918-1919 influenza pandemic years, larger proportions of young adults died, sometimes following an abbreviated course of illness marked by cyanosis and hemorrhagic manifestations.

During World War I, U.S. Army Surgeon General William Gorgas developed a series of commissions to gather the best civilian and military input on ongoing and recurring infectious disease problems. In the spring of 1918, a Pneumonia Commission was formed. In 1941, the Army established the Board for the Investigation and Control of Influenza and Other Epidemic Diseases in the Army, which evolved into the Army Epidemiological Board in 1944 and the Armed Forces Epidemiological Board (AFEB) in 1949 [5]. Influenza strains were obtained from Thomas Francis, Jr., the first director of the Commission on Influenza, AFEB, who later served as president of the AFEB (1958-1960) and also served as director of the Department of Epidemiology at the University of Michigan's School of Public Health. (Of note, the live-attenuated influenza vaccine licensed in 2003 also originated at the University of Michigan.) Francis is credited with having been the first scientist to isolate influenza virus from a human in the United States in 1935 and also the first to isolate influenza B. The influenza virus strains contributed by Dr. Francis were used to make an inactivated whole-virus vaccine evaluated by clinical studies in hospitalized inmates, military recruits, and college students [6-8]. U.S. Army troops were vaccinated against influenza type A starting in 1943 prior to influenza vaccine licensure by Parke, Davis and Company of Detroit, Michigan in 1945 because of concern that mobilization of troops could enhance influenza transmission resulting in another serious pandemic. A bivalent vaccine was produced adding inactivated influenza type B virus starting in 1945 following the demonstration of protective efficacy of the type B vaccine. The majority of U.S. Army troops were given bivalent influenza vaccine by November 1945 per orders from the Army Surgeon General on 10 August 1945. An increasing incidence of influenza B was noted in the United States during November and December 1945, but it was reported that Army personnel who had received influenza vaccine experienced a much lower incidence of illness than unvaccinated Navy and civilian groups [5]. Because the type A vaccine failed to protect against a new "A-prime" subtype of influenza type A in 1947, this A-prime subtype was added to produce a trivalent inactivated vaccine. Subsequently, a policy to change vaccine virus subtypes based on circulating influenza strains was initiated following recognition that antigenic shifts impacted influenza virus transmission in humans [9]. 
The vaccine used to combat the 1957 influenza pandemic utilized a viral strain isolated from a sick U.S. sailor returning from a port call in Hong Kong by U.S. Army investigators stationed in Japan. The virus was sent to Maurice Hilleman (then at the Walter Reed Army Institute of Research [WRAIR] in Washington, DC) for characterization. Subsequently, the virus was shared with the NIH Division of Biologics Standards, which then provided the strain to industry [10]. In 1976, an outbreak of influenza on a military post caused by a virus similar to the causative agent of the 1918-1919 pandemic resulted in an effort to immunize the entire population of the United States [11-13]. Because of reports of Guillain-Barre syndrome in civilian (but not military) recipients of influenza vaccine, the immunization effort was terminated [14-16].

The U.S. military has supported other studies investigating the transmission and prevention of influenza in military populations, and components of the U.S. military continue research on influenza and influenza vaccines [17-23]. Between 1961 and 1993, the AFEB made 53 separate recommendations regarding the composition of influenza vaccines. More recently, the Assistant Secretary of Defense (Health Affairs) has issued several policy statements per year guiding the DoD in influenza management, and DoD representatives often participate in the FDA advisory committee that reviews influenza-related products.

\section{Rubella vaccine}

German researchers first described the disease "German measles" - later known as "rubella" from the Latin "rubellus" meaning "reddish" - as distinct from measles in 1814. Rubella is caused by a single-stranded RNA virus that spreads person-to-person (humans are the only known host) via respiratory droplets. The rubella virus causes fever and rash, which is followed by prolonged joint pain and inflammation in rare cases. However, in early gestation rubella infection can result in serious fetal malformations (hearing impairments, heart defects/inflammation, mental retardation, brain inflammation, hepatomegaly, splenomegaly, and thrombocytopenia [24]).

Prior to 1969 , U.S. military recruits and military hospital workers (particularly women of childbearing age) were at risk for rubella infection and sequelae. Beginning in 1947, pregnant women exposed to rubella were given convalescent serum or immune serum globulin to prevent fetal infection. A rubella pandemic that hit Europe in 1962 and then caused 12.5 million cases of rubella and 2000 cases of rubella encephalitis in the United States from 1963-1964, with 30,000 afflicted infants (1\% of all pregnancies, with 6250 spontaneous abortions and 2100 excess neonatal deaths) prompted rubella vaccine efforts.

In 1961, Lieutenant Colonel (LTC) Edward Buescher, U.S. Army Captain (CPT) Malcolm Artenstein, and CPT Paul Parkman of WRAIR isolated the rubella virus from a recruit hospitalized at Fort Dix during an adenovirus outbreak investigation after noting interference with enteroviral growth in African green monkey kidney cell cultures - a technique pioneered by scientists at WRAIR. (Thomas Weller and Franklin Neva also isolated the rubella virus at Harvard University in 1962.) Parkman then moved on to the Division of Biologics Standards at NIH, where, together with Harry Meyer, he used the isolated HPV-77 virus grown in duck-embryo culture to create Meruvax (Merck) - a live-attenuated viral vaccine manufactured by Merck Sharp \& Dohme that was one of three rubella vaccines licensed in the United States in 1969 (a different viral strain [RA 27/3] was used as the basis of Meruvax II beginning in $1979[25,26])$.

The impact of rubella vaccine has been dramatic. During the 3 years before vaccines were brought to market in 1969, 47,745 cases of rubella were recorded in the United States. As of 2005, the U.S. Centers for Disease Control and Prevention announced that rubella virus infection was no longer endemic in the United States [27].

\section{Adenovirus vaccines (types 4 and 7) and related research efforts}

Acute respiratory disease (ARD) caused by a variety of pathogens has been a long-standing important cause of morbidity and sometimes mortality among military personnel (particularly recruits), attributed in part to crowded living conditions and physical stress. Adenovirus - a frequent cause of epidemic ARD associated with pneumonia, hospitalizations, and some deaths - is a proven threat to military readiness and also causes illness among civilians [26,28].

Adenoviruses are DNA viruses that are usually transmitted via respiratory (aggravated by crowding) or ocular (related to lack of hand washing) routes. Asymptomatic infection and a prolonged carrier state contribute to spread. Diseases associated with adenoviral infections include febrile respiratory illness (bronchitis or pneumonia), eye infections (conjunctivitis), pharyngitis, and diarrhea. Complications of adenovirus include acute otitis media, pneumonic infections, and death. There is no effective antiviral treatment for adenovirus at the present time.

During World War II, epidemics of respiratory disease in recruits disrupted training and greatly increased the burden on medical staff and facilities. A commission on ARD was established at Fort Bragg in North Carolina from 1942 to 1945 to undertake epidemiological studies. The viral nature of these infections was established when bacteria-free filtrates were shown to transmit the infection to volunteers. The impact of ARD on recruits undergoing Basic Combat Training (BCT) was assessed in prospective studies in the 1950s, when Maurice Hilleman and his co-workers established that $20 \%$ of recruits were hospitalized with febrile ARD, another $20 \%$ sought evaluation at an outpatient facility, $40 \%$ had mild or inapparent infections, and the remaining $20 \%$ (probably immune) were not infected. In a similar subsequent study 
of an ARD outbreak in recruits at Fort Dix in the 1960s, Buescher and his co-workers observed that $37 \%$ were hospitalized with febrile ARD and an additional $48 \%$ were also ill with less severe infections.

In the course of investigating an influenza epidemic at Fort Leonard Wood in 1952-1953, Hilleman and J.H. Werner at WRAIR identified adenovirus types 4 and 7 , which cause the vast majority of clinically apparent adenovirus infections afflicting unvaccinated recruits during BCT, and established the importance of neutralizing antibody as a marker of immunity for these infections [29,30]. Before vaccines were available, adenovirus was consistently isolated in 30-70\% of trainees with ARD, and adenoviruses were associated with $90 \%$ of the cases of pneumonia among trainees in BCT [31,32].

Effective formalin-inactivated parenteral types 4 and 7 vaccines were licensed by the FDA in 1956, but the license was revoked in 1963 because of manufacturing problems including variable potency and concerns regarding potential oncogenicity due to contamination with SV-40 [33]. Because ARD epidemics caused by adenovirus types 4 and 7 continued, R.M. Chanock, W.P. Edmondson, F.H. Top, Jr., and co-workers at WRAIR developed highly antigenic live oral adenovirus types 4 and 7 vaccines. These oral types 4 and 7 adenovirus vaccines were effective in decreasing cases of ARD resulting in hospitalization of recruits by $50 \%$ without producing adverse effects and were approved by the FDA for distribution by Wyeth Laboratories in 1980 [34-37].

In 1995, Wyeth - the sole manufacturer of adenovirus vaccines - ceased production of these vaccines when faced with an FDA requirement for costly updated manufacturing facilities for the vaccine. DoD supplies of adenovirus type 4 vaccine and adenovirus type 7 vaccine were depleted by 1998 and 1999, respectively. Since termination of Wyeth vaccine production, the burden of adenovirus disease in recruits has increased to that of the pre-vaccine era. Further, a study found that nearly $90 \%$ of new recruits were seronegative for either type 4 or 7 adenovirus, and therefore susceptible to adenovirus infection $[38,39]$. Because of the surge of adenovirus cases, the DoD contracted with Barr Laboratories (now Barr Pharmaceuticals) in September 2001 to develop replacement live types 4 and 7 adenovirus vaccines. The first clinical study of the new adenovirus vaccines has been successfully completed by investigators at Fort Sam Houston, and a Phase 3 trial commenced in September 2006.

\section{Meningococcal vaccines}

Neisseria meningitidis, the causative agent of meningococcal meningitis, is a Gram-negative bacterium with the microscopic appearance of two kidney beans aligned along their long axis. The bacteria are encapsulated by a polysaccharide coat, which contains an important determinant of potential virulence. Five antigenically distinct capsular polysaccharide serogroups, designated groups $\mathrm{A}-\mathrm{C}, \mathrm{Y}$, and $\mathrm{W}-135$, account for almost all human disease, although 13 groups have been identified.

The bacteria are transmitted via infected respiratory droplets under conditions favoring close person-to-person contact. Humans serve as the only host and reservoir for $N$. meningitidis infections. Meningococcal bacteria may either harmlessly colonize the human nasopharynx or become invasive pathogens causing bacterial sepsis and meningitis. Invasive meningococcal infections cause significant morbidity (sudden fever, headache, nausea, rash, delirium, and coma) and rapid mortality (the case-fatality ratio for all invasive meningococcal disease is estimated to be 11\%) [40]. Whether a given meningococcal infection will result in an asymptomatic carrier state or in a devastating systemic disease depends on host immunity, bacterial virulence, and other factors (lack of a spleen, cigarette smoking, viral upper respiratory infections, and alcohol consumption are associated with increased risk of disease).

Infections with $N$. meningitidis bacteria occur globally. Large-scale epidemics afflict Africa (particularly in the subSaharan region) during the dry season. As is the case with adenovirus infections, increased risks of meningococcal infections are associated with close exposures to large groups of people from diverse locales who are under stress. The risk of meningococcal disease transmission to pilgrims to the Islamic holy city of Mecca in Saudi Arabia (and to subsequent contacts of the pilgrims) has been recognized for decades. The highest incidence of bacterial meningitis occurs in children under the age of 5 years, but there is a second peak in disease incidence among teenagers and young adults.

Outbreaks of meningococcal disease among military recruits and soldiers have been documented since the nineteenth century, although the etiology was not recognized until later. Epidemic disease erupted among U.S. troops during World War I. Because a similar experience was predicted with the U.S. entry into World War II, the Army's newly formed epidemic diseases board created a Commission on Meningococcal Meningitis (1941-1946) to accelerate scientific study of the disease. The commission documented more than 5000 domestic cases among U.S. Army personnel occurring between 1941 and 1943, mostly in soldiers during the first 3 months of military service. During the period from 1964 to 1971, coincident with the Vietnam War, an epidemic of groups B and C meningococcal disease occurred in U.S. military basic training centers, resulting in temporary closing of Fort Ord in California. Approximately 2400 cases occurred in active duty military personnel with a case-fatality ratio of about $7.2 \%$ (about 170 deaths). During the Vietnam War, there were at least as many deaths among U.S. military personnel attributed to meningococcal disease as were attributed to malaria. This epidemic and the high rate of emergence of meningococcal strains resistant to prophylactic antimicrobials led to an intensive effort at WRAIR to develop vaccines to protect military service members [41]. 
Beginning in 1963, a team of investigators, led by Malcolm Artenstein, Emil Gotschlich, and Irving Goldschneider conducted studies over a 5-year period that elucidated the human immunological response to meningococcus and provided a basis for the successful development of effective polysaccharide vaccines for serogroups A and C [42-48]. The concept of using polysaccharides as immunogens was an outgrowth of work on pneumococci performed at the Rockefeller Institute in the 1930s and 1940s that led to a successful trial of a tetravalent pneumococcal polysaccharide vaccine among military personnel in 1945 [5]. The WRAIR team's contributions included development of methods for purification of high molecular weight polysaccharides from groups A-C; physical and chemical analysis of the polysaccharides; and immunogenicity studies in several animal species.

WRAIR scientists created the first subunit vaccine designed to prevent type $\mathrm{C}$ infections and completed Phase 1-3 clinical trials involving production of clinical grade vaccine that demonstrated safety and high efficacy and culminated in the licensure of the vaccine. The Phase 3 trials required a large sample size and multiple locations given the relatively low incidence of meningococcal disease, the lack of exact predictability of the location of an outbreak, and the impact of vaccinated persons on illness transmission (herd effect). Such trials also required careful organization, because informed consent and vaccinations in new recruits had to be accomplished within days of arrival before acquisition of the carrier state. In the first efficacy study, 13,763 men at five different military posts were vaccinated with a group $\mathrm{C}$ polysaccharide vaccine, and more than 53,000 men served as unimmunized control subjects. The vaccine safely reduced the acquisition rate of group $\mathrm{C}$ meningococci (although not that of other meningococcal groups) and the rate of systemic meningococcal disease caused by group $\mathrm{C}$ organisms during an 8-week period [47]. A second large field trial yielded similar results [48].

This meningococcus polysaccharide $\mathrm{C}$ vaccine began to be used for routine vaccination of recruits entering basic training in 1970 and was replaced by an A/C divalent vaccine in 1978. Work on the development of vaccines for serogroups $\mathrm{Y}$ and $\mathrm{W}-135$ and testing of a tetravalent $\mathrm{A}, \mathrm{C}, \mathrm{Y}, \mathrm{W}-135$ vaccine took place independently at several institutions including Connaught Laboratories, WRAIR, Institut Mérieux, and the Rixensart, Belgium branch of Smith Kline between 1975 and 1981. The groups Y and W-135 capsular polysaccharides were purified and characterized by these different institutions using the same methods developed at WRAIR for the groups $\mathrm{C}$ and A vaccines [49,50]. Connaught Laboratories' purified capsular polysaccharide A, C, Y, W-135 tetravalent vaccine (commercial name: Menomune), licensed by the FDA in November 1981, was based on the company's own clinical data. A tetravalent meningococcal vaccine is indicated for military recruits, persons lacking spleens, individuals with terminal complement deficiencies, travelers to areas where meningococcal disease is hyperendemic or epidemic, and subgroups of college students [51-54]. A protein-conjugated tetravalent meningococcal vaccine (Menactra) was licensed to Aventis Pasteur by the FDA on 14 January 2005, and should be of particular value to young children, for whom polysaccharides are poorly immunogenic, but will also be used henceforth by the U.S. military [55].

A group B meningococcal vaccine has been under development at WRAIR since 1969. Since the epidemic in the 1960s, group B disease has remained at a relatively low level with occasional small clusters of cases occurring at different training posts. However, group B meningococcal disease remains a threat for the U.S. military, in part because the rapid onset of severe, potentially fatal disease and risk of transmission to close contacts result in a high level of concern and disruption to normal operations. Group B N. meningitidis is currently responsible for about $25-90 \%$ of all meningococcal disease in North and South America and in most European countries. Over the past 25 years, group B epidemics have occurred in Norway, Cuba, Chile, Brazil, and New Zealand. Many of these epidemics have been caused by a single genetic clone known as ET-5, which is particularly virulent and first appeared in Norway in the 1970s. Development of a vaccine against serogroup B - a much more difficult task compared to development of a vaccine for the other meningococcal serogroups due to antigenic similarity between the group B strain capsule and components of human nerve cells - requires identification of a stable immunogenic antigen common to all serogroup B meningococci or formulation of a multivalent vaccine providing protection against a large portion of group B antigenic variants. This effort has been slowed by the antigenic variation and/or phase variation associated with most of the antigens that have been demonstrated to induce bactericidal antibodies and by the lack of a good animal model for the disease. Nevertheless, research on potential antigens created from native outer membrane vesicles (NOMV) and detoxified lipooligosaccharides (dLOS) continues. A series of candidates have been evaluated in humans [56-59].

\section{Hepatitis B vaccine}

Hepatitis B virus (HBV) is transmitted by blood-to-blood and sexual contact and is an important cause of acute and chronic hepatitis in many countries. The clinical features of acute hepatitis B infection resemble those caused by other hepatitis viruses. The HBV virus persists in approximately $5-10 \%$ of healthy adults, and in as many as $90 \%$ of infants infected at birth. Persistent carriage of hepatitis B, defined as the presence of hepatitis B surface antigen (HBsAg) in serum for more than 6 months, has been estimated to affect about 350 million people worldwide, although not all carriers can transmit the virus to others. Long-term continuing HBV replication can result in chronic liver disease, cirrhosis, and hepatocellular carcinoma, and results in 1-2 million deaths per year. Primary liver cancer is among the 10 most common 
cancers worldwide, and currently $80 \%$ of such cancers are ascribed to persistent infection with HBV.

Soldiers are at risk for exposure to HBV via contaminated blood and body fluids during battle and sexual intercourse. Acute hepatitis was one of the main causes of illness among military personnel during the Vietnam War. A significant part of this was probably a consequence of contaminated needle use. Some service members from Vietnam and other wars continued injected drug use after returning to the United States and remained at risk from hepatitis B from shared needles.

The U.S. military became focused on hepatitis B after the summer of 1942, when 50,000 cases of jaundice and 62 deaths occurred among soldiers vaccinated with yellow fever vaccine $[60,61]$. Investigators attributed the illness to a virus transmitted from human serum used in vaccine manufacture [62]. The epidemic ceased after suspect vaccine lots were destroyed, and a human serum-free process whose development was led by U.S. Public Health Service officer Mason V. Hargett was utilized [63]. Investigations of stored samples many years later confirmed that the causative agent was HBV.

Beginning in 1944 and continuing through the 1970s, the U.S. Army Surgeon General's office supported studies at Yale University and the Willowbrook State Hospital in New York that characterized the epidemiology and required immunoprophylaxis for two different viral causes of epidemic hepatitis, including hepatitis B. Following Baruch Blumberg's discovery of the Australia antigen (HAA, now known as HBsAg) in 1965, the association of this antigen with hepatitis B was recognized, which made possible additional epidemiological studies linking hepatitis B with intravenous drug abuse and sexual exposure.

In the late 1960s, scientists at the U.S. Army Medical Research Laboratory at Fort Knox, Kentucky collaborated in a study of more than 1600 service members; the cohort included both soldiers who had recently returned from Vietnam and recruits who had not yet been to Southeast Asia. A significantly higher frequency of HBsAg carriers was noted among the returnees (about 0.7\%) than among the recruits $(0.2 \%)$. In the early $1970 \mathrm{~s}$, a second larger study involving nearly 20,000 Vietnam War returnees and recruits was initiated that also incorporated data from returnees participating in a drug rehabilitation program. The higher $\mathrm{HBsAg}$ rate among newly returned service members was attributed to HBV acquired via injected drug use, but some returnees initially testing positive eventually became $\mathrm{HBsAg}$ negative due to presumed recovery from HBV $[64,65]$.

These studies sponsored by the U.S. military helped document the need for a hepatitis $B$ vaccine. The first-generation hepatitis B virus (HBV) vaccine (Heptavax B, which was licensed by the FDA to Merck Sharp \& Dohme in 1981) was prepared from 22-nm HBsAg particles purified from plasma donations from chronic HBV carriers [66]. These preparations (not tested by the U.S. military) are safe and immunogenic, but have been replaced in most countries by recombinant vaccines produced by the expression of recom- binant HBsAg in yeast cells. Current HBV vaccines utilize subtype "adw." Investigators at WRAIR carried out early work on subtyping strains of HBsAg from different geographic regions and first described the " $w$ " and " $r$ " antigenic determinants [67]. While working at the Southeast Asia Treaty Organization (SEATO) Medical Research Laboratory in Thailand (which became the Armed Forces Research Institute of Medical Sciences [AFRIMS] in 1977), William Bancroft found that saliva from humans with chronic hepatitis B contained infectious HBV [68].

\section{Typhoid vaccine (oral live typhoid Ty21a vaccine)}

Typhoid fever, an acute generalized illness primarily striking adolescents and young adults caused by infection with the bacterium Salmonella typhi, is characterized by fever, headache, abdominal pain, mild erythematous macular rash ("rose spots"), and bowel movement and mental changes. The word "typhoid" is derived from the Greek "typhos" (delirious) because the disease is associated with mental confusion. S. typhi, which causes infection only in humans, is acquired by ingestion of contaminated food or water or finger-tomouth contact with contaminated feces. The infection can be spread by a healthy carrier of the bacterium ("Typhoid Mary"), a person ill with the disease, or contaminated flies. Major complications include gastrointestinal hemorrhage, bowel infarction with peritonitis, pericarditis, meningitis, and septic arthritis, and the disease may be fatal in untreated susceptible persons.

During the Spanish-American War, one-fifth of U.S. troops (mostly U.S. Army personnel) had typhoid fever, and over 1500 persons died of the disease; some acquired the infection in U.S. training camps before going overseas. In the Anglo-Boer War, the British army lost more men to typhoid (8225 deaths) than it did to wounds (7582 deaths). Development of a typhoid vaccine became a priority for both nations [69].

Observational studies dating back to the Civil War (when 44,558 Union soldiers died of diarrhea or dysentery compared with 110,070 combat-related deaths) revealed that some typhoid fever survivors were not susceptible to repeat bouts of this illness [70]. This evidence of natural immunity prompted efforts to develop vaccines to prevent typhoid fever. The first typhoid vaccines were created in Britain in 1896 by Sir Almroth Wright. After Major (MAJ) Frederick Russell of the U.S. Army modified this vaccine to create a subcutaneous form and conducted studies in volunteers demonstrating safety and efficacy, typhoid immunization was required of U.S. service members beginning on 30 September 1911 [71]. Typhoid vaccine was licensed in the United States in 1914. This vaccine prevented outbreaks of typhoid fever in U.S. Army troops dispatched to the U.S.-Mexican border because of the Mexican revolution. The U.S. Army became the first military organization in the world to make typhoid vaccination mandatory and had the lowest typhoid 
fever incidence of any major combatant in World War I. Furthermore, despite the relatively low efficacy of all typhoid vaccines used in highly endemic areas in comparison to other vaccines co-developed by the $\mathrm{DoD}$, no major typhoid outbreaks have impacted deployed U.S. forces in subsequent wars [72-74].

Advances in microbiology have led to a dramatic reduction in the number of cases of severe diarrhea in the developed world, but typhoid fever and other diarrheal illnesses remain an important problem in countries that lack clean water and well-functioning sanitation systems. Because typhoid remains a threat to U.S. troops deployed to such areas, and early typhoid vaccines were associated with some adverse effects, newer vaccines have been created. The U.S. military contributed to the development of the more recently licensed oral typhoid vaccine. M.M. Levine and others conducted large-scale DoD-funded studies in the 1980s in collaboration with the Chilean Ministry of Health that demonstrated 67\% efficacy of an enteric-coated vaccine based on an attenuated Ty21a strain of $S$. typhi in conditions of moderate typhoid fever transmission in Chile [75-77]. Later that decade, C.H. Simanjuntak and others at the U.S. Naval Medical Research Unit No. 2 (NAMRU-2) in Jakarta and the Indonesian Ministry of Health demonstrated $42 \%$ efficacy of this vaccine in a setting of intense transmission of typhoid fever in Jakarta [78]. Berna Products (now Acambis) was granted licensure by the FDA in December 1989 for the attenuated live oral enteric-coated vaccine based on Ty21a. As is the case with all typhoid vaccines, whether given by mouth or injection, recipients are also advised to take other preventive measures against typhoid, such as practicing good hygiene.

The U.S. military has contributed to control of typhoid fever in other ways: (1) Identification of pathological bowel findings (such as enlarged intestinal lymphoid follicles or "Peyer's patches") during autopsies by U.S. Civil War surgeons were eventually linked to typhoid infection. (2) In 1899, during the Spanish-American War, the Reed-VaughanShakespeare Typhoid Board was established. This board, with MAJ Walter Reed, MAJ Victor C. Vaughan, and MAJ Edward O. Shakespeare, carried out epidemiological investigations focusing on typhoid fever and noted that the U.S. Army had failed to undertake established sanitary measures to prevent typhoid fever during the Spanish-American War. Another important observation of the Typhoid Board was that either sick or healthy human carriers of typhoid bacilli were important sources of typhoid infection. (3) MAJ Carl Darnall developed a method of water purification in 1910, and MAJ William Lyster developed a water purification system using calcium hypochlorite in a linen bag (Lyster bag) in 1915. These techniques have improved the safety of water supplies for both military personnel and civilians around the world.

The U.S. military has also contributed to improved treatments for typhoid fever patients. In 1948, Joseph Smadel, Theodore Woodward, Herb Ley, and Charles Wissman of WRAIR noted that a patient given chloramphenicol for scrub typhus had typhoid fever responsive to chloramphenicol [79]. Subsequently, investigators at NAMRU-2 (Jakarta, Indonesia) and NAMRU-3 (Cairo, Egypt) have demonstrated the utility of other antimicrobial agents such as ciprofloxacin, azithromycin, and third-generation cephalosporins for typhoid fever [80-83]. In 1984, Stephen Hoffman and others revealed the usefulness of the corticosteroid dexamethasone in reducing mortality from severe typhoid fever [84]. In the 1960s, CPT Robert Phillips developed intravenous and oral rehydration techniques useful in preventing dehydration caused by all forms of severe infectious diarrhea that are estimated to have saved many millions of lives [85].

\section{Japanese encephalitis vaccine and current related research}

Japanese encephalitis virus (JEV; previously called Japanese encephalitis type B) is a flavivirus transmitted by mosquitoes that is associated with outbreaks of encephalitis in Asia, the Pacific Islands, Northern Australia, and Russia. JEV transmission is generally seasonal and limited to rural areas (pigs and birds are important for viral maintenance, amplification, and spread). Within Asia, Japanese encephalitis (JE) is the most important cause of human encephalitis and causes approximately 35,000 cases and 10,000 deaths annually. Although between 25 and 1000 asymptomatic JEV infections occur for each identified clinical case of JE, and symptoms may be limited to mild illness with fever in some persons, the case-fatality ratio for persons with evident disease is about $25 \%$, and at least $50 \%$ of JE survivors have sequelae ranging from mood changes to severe neurological impairment [86]. Currently, there is no effective treatment of JE beyond supportive care. Use of pesticides results in minor reductions of JEV vectors in a limited area for a short period of time at considerable cost.

JEV was first isolated in 1935 from the brain of a patient dying of encephalitis in Japan. At the beginning of World War II, anticipating possible epidemics among U.S. forces in the Pacific, the Commission on Neurotropic Virus Diseases of the Army Epidemiological Board assigned MAJ Albert Sabin the task of developing a vaccine against JE. A crude vaccine derived from formalin-inactivated brains of mice infected with JEV was developed (based on the earlier work of Japanese and Russian scientists) and administered to approximately 250,000 military personnel during World War II, beginning shortly after a 1945 JE outbreak among U.S. troops in Okinawa. In addition, Sabin and others recorded clinical descriptions of laboratory-confirmed cases and performed studies to identify the natural vectors and reservoirs of the virus.

The need for a more efficacious vaccine became apparent during U.S. involvement in the Korean War, when there were 299 cases of proven or suspected JE among U.S. forces despite administration of JE vaccine to all U.S. troops in the 
Far East Command between 1946 and 1951 (at which point the U.S. Army ceased JE vaccine administration).

The ecology of JEV was elucidated in greater detail by WRAIR investigators Buescher and Scherer working in Japan in the late 1950s [87]. Increased demand for a JEV vaccine for U.S. civilians began in 1981, when a 20-year-old student from Washington, DC contracted fatal JE while attending Beijing University. Japanese encephalitis vaccine trials were conducted in the United States by the U.S. Centers for Disease Control (CDC) beginning in 1983 under Investigational New Drug Application authorization from the FDA.

In the mid-1980s, a DoD team led by Charles Hoke with collaborators in the Thai Ministry of Public Health conducted the definitive study evaluating two doses (given 1 week apart) of the highly purified BIKEN vaccine (NakayamaYoken strain) versus a bivalent vaccine (Nakayama-Yoken and Beijing-1 strains) versus placebo (tetanus toxoid). There were approximately 22,000 Thai schoolchildren in each of these recipient groups. The efficacy of both monovalent and bivalent vaccines was $91 \%$, achieved with minor vaccine adverse effects (headache, sore arm, rash, and swelling), and these data [88-91] were pivotal in obtaining FDA licensure of JE-VAX - a formalin-inactivated whole virus vaccine on 10 December 1992. This large clinical trial was facilitated by (1) development of a new IgM test by Donald Burke at AFRIMS and (2) the comprehensive placebo-controlled study of the BIKEN vaccine in volunteers in the 25th Infantry Division in Hawaii, which demonstrated that the vaccine was safe and antibody levels persisted 3 years after immunization $[88,92,93]$. This is currently the only FDA-licensed vaccine for Japanese encephalitis. The manufacturing company was the Research Foundation for Microbial Diseases of Osaka University (BIKEN), and the vaccine was distributed in the United States by Sanofi Pasteur. An initial three-dose regimen (plus booster doses) is recommended by the CDC for optimal immune response.

BIKEN/Sanofi Pasteur discontinued production of JEVAX in 2005 in part because of concern about (non-lifethreatening) adverse vaccine effects. Because it is anticipated that the entire DoD stockpile of available JE-VAX will have been expended by the 2008 fiscal year following utilization by Navy personnel and Marines deployed to Asia, WRAIR and other U.S. military laboratories have collaborated with a commercial partner (Intercell) to test a second-generation formalin-inactivated Vero cell culture-based JEV vaccine formulated with alum.

\section{Hepatitis A vaccine}

Hepatitis A virus (HAV) - a non-enveloped, singlestranded RNA virus - is endemic worldwide, although rates of transmission vary depending on national income level (a surrogate for sanitary infrastructure). The virus is transmitted when food or water becomes contaminated with feces of infected persons. In developing nations, the virus is gener- ally acquired early in life and rarely causes severe symptoms. In developed nations with better sanitation, infection with hepatitis A may be delayed until an individual travels to an underdeveloped area or there is an unusual breakdown in sanitation. Infections in adults may be associated with serious symptoms and rare fatalities.

Epidemics of hepatitis A have repeatedly afflicted the U.S. military during deployments to regions with suboptimal sanitation, water, and waste systems. During the Civil War, epidemic hepatitis (most likely due to hepatitis A virus) was common, but few deaths were recorded. During the second year of the war, about 50 of every 1000 men became jaundiced; only about half this number were diagnosed in subsequent years of the war. Although improved sanitation may have contributed slightly to the decrease, it is more likely that veteran soldiers were eventually exposed to the disease and acquired immunity [94]. In World War I, hepatitis was a serious problem for British, French, and German troops, but less of a problem for U.S. troops. U.S. forces experienced greater than 180,000 cases of infectious hepatitis in World War II, with 106,695 inpatient admissions and a case-fatality ratio of $0.3 \%$. The annual admission rate per 1000 was 4.37 overall, with the highest rates of disease in the southwest Pacific and the Mediterranean. During the Korean War, outbreaks of hepatitis occurred in 1950 and 1951 related to poor sanitation during intense conflicts, and more than 4000 troops with hepatitis were hospitalized or restricted to quarters.

Outbreaks of hepatitis A disease have affected the military during peacetime. In 1959, uncooked fish was implicated in an outbreak in Naples involving 156 persons on 14 ships. In 1974, a food handler was suspected of causing a large number of cases (47/1000 attack rate) in San Diego. In 1980, child care centers were recognized as a focus for hepatitis A transmission on military posts.

In 1945, the U.S. military played a role in demonstrating that passive immunization with immune globulin (IG) from pooled human plasma could prevent or attenuate hepatitis A disease [95]. A randomized, double-blind study involving 107,803 U.S. soldiers, led by COL Marcel Conrad during the Korean War, showed that service members given 5-10 $\mathrm{ml}$ IG containing antibodies to hepatitis A and B by intramuscular injection on arrival in Korea were protected from icteric hepatitis caused by hepatitis A, hepatitis B, and non-A, non-B hepatitis for 6 months [96,97]. This research supported the concept that vaccines that elicited appropriate antibody responses could provide protection against viral hepatitis. However, immune globulin, which was used for a time to protect soldiers and civilian travelers from infection with hepatitis $\mathrm{A}$, requires repeated injections and is not readily available at present. Also, with large and lengthy deployments, distribution of IG has proved impractical and unpopular in the military [26].

Much of the development of the FDA-licensed inactivated hepatitis A vaccine Havrix is attributable to the U.S. military in partnership with NIH and SmithKline Beecham (SKB, now GlaxoSmithKline). Techniques to quantify hepatitis A virus 
and associated antibodies were developed at WRAIR. At WRAIR and NIH (laboratory of Robert Purcell), numerous cell types were evaluated for their ability to support growth of hepatitis A virus, and optimal growth parameters were defined. Both guinea pigs and monkeys developed excellent titers of neutralizing antibody following immunization with a prototype formalin-inactivated vaccine created by L.N. Binn, D.R. Dubois, and K.H. Eckels [98,99]. Analysis of strains from international sources showed antigenic similarity and indicated that a vaccine need contain only a single serotype to provide global protection against HAV. Human trials began at WRAIR in 1986 with formalin-inactivated vaccine; all eight volunteers developed neutralizing antibody after four small doses of vaccine antigen. The DoD established cooperative agreements with SKB for hepatitis A vaccine development in 1989. Initial small-scale collaborative investigations evaluated antibody responses in humans following immunization with two candidate vaccine strains. A 1991 study of coadministration of hepatitis A vaccine with hepatitis B vaccine to soldiers found no immune interference between vaccines. This finding eventually resulted in another 1991 study showing that accelerated hepatitis A immunization schedules were effective for service members. A large-scale field efficacy trial of hepatitis A vaccine (showing 94\% efficacy) was begun in 1991 (led by LTC Bruce Innis) as a collaborative project of the U.S. Army, Thailand's Ministry of Public Health, and SmithKline Beecham Biologicals. In this trial, approximately 20,000 volunteers received hepatitis A vaccine and 20,000 received a control vaccine (hepatitis $B$ vaccine). Havrix, the inactivated hepatitis A viral vaccine manufactured by GlaxoSmithKline, was licensed by the FDA in February 1995 [65,100]. Two doses administered 6 months apart are believed to confer lifetime immunity. The DoD was not directly involved in the licensing of Vaqta, a second inactivated hepatitis A vaccine, by Merck in 1996.

The DoD also supported Phase 1 and 2 studies of a recombinant hepatitis E virus (HEV) vaccine. HEV - a nonenveloped, single-stranded positive sense RNA virus - is transmitted via the fecal-oral route and causes acute disease in developing countries (particularly in Africa and Asia) both sporadically and in epidemics, causing considerable morbidity and mortality, especially in pregnant women. A three-dose recombinant protein HEV vaccine study involving collaboration between the U.S. military, NIH, GlaxoSmithKline, and the Royal Nepalese Army revealed 95.5\% vaccine efficacy without notable adverse effects [101].

\section{Other past U.S. DoD-related vaccine efforts}

Development of other licensed vaccines was supervised by investigators who began their careers at military research centers. For example, yellow fever vaccine development was spearheaded by former Army Surgeon General William Gorgas while employed at the Rockefeller Foundation, and this effort was supported by active members of the U.S. military. Gorgas previously directed the vector control programs that eliminated yellow fever in the Panama Canal area during the canal's construction. Maurice Hilleman, who is credited with the codiscovery of adenoviruses and important influenza research while working as a civilian at WRAIR, also played a key role in the development of mumps, measles, varicella, and other vaccines after joining Merck. Oral polio vaccine was developed by Albert Sabin, who worked on influenza and Japanese encephalitis vaccines prior to retirement from the U.S. Army.

Also, the U.S. military contributed to the early work for two vaccines later taken on by other investigators. The first clinical trial of multivalent pneumococcal polysaccharide vaccine - largely based on Michael Heidelberger's work at the Rockefeller Institute in the early 1940s - was conducted at the U.S. Army Air Base in Sioux Falls, South Dakota under the direction of the U.S. Army Epidemiological Board's Commission on Pneumonia. Administration of this vaccine was associated with reduced incidence of pneumonia and pneumococcal carrier rates. These important findings did not immediately result in a commercially successful vaccine (a 14-valent pneumococcal vaccine licensed in the United States available from E.R. Squibb from 1947 to 1954 was an economic failure because physicians preferred to use newly available penicillin to treat pneumococcus infections rather than rely on a prophylactic vaccine) [26]. However, the demonstration of a polysaccharide pneumococcal vaccine enticed researchers to investigate polysaccharide approaches for development of meningococcal vaccines.

Interest in the pneumococcal vaccine was revived in 1963 when Robert Austrian, professor of medicine at the University of New York Downstate Medical Center and later professor of research medicine at the University of Pennsylvania, documented the continuing importance of pneumococcal bacteremia in South African miners. A protein-conjugated seven-valent form of the vaccine capable of eliciting immunity in young children was licensed by the FDA to Wyeth-Lederle in 2000. The growing problem of antimicrobial-resistant pneumococci and development of a protein-conjugated pneumococcal vaccine for children has resulted in more widespread use of pneumococcal vaccines.

Since 1945, the U.S. military has been a leader in the development of vaccines to prevent diseases caused by rickettsiae and related bacterial pathogens, including epidemic typhus and scrub typhus. Because louse-borne typhus had caused devastating epidemics (mostly afflicting civilians and soldiers in Eastern Europe and Russia) during and immediately after World War I, U.S. military officers and U.S. Public Health Service officials traveled to Canada shortly after the Japanese attack on Pearl Harbor to assess rickettsial vaccine progress at Connaught Laboratories. The Division of Biologics Control licensed a new vaccine for louse-borne typhus in 1941 which was administered to U.S. personnel deployed to southern Europe and North Africa. This was the first rickettsial vaccine; it was produced by growing the bacteria in 
fertilized hen's eggs (chick embryo), which was a new technique at the time. Only 64 louse-borne typhus cases occurred among U.S. military personnel in World War II $[102,103]$.

The U.S. military is currently attempting to develop a scrub typhus vaccine that protects deployed service members from a variety of strains of Orientia tsutsugamushi (previously referred to as Rickettsia tsutsugamushi). The infection, which can cause high fever with a long convalescence or death, is prevalent in Asia, Australia, and many Pacific islands and is transmitted to humans via the bite of infected chiggers (larval mites of the Trombiculidae family). Scrub typhus hindered U.S. and allied troop strength during World War II and the Vietnam War, and outbreaks occurred among U.S. Marines training in Japan in 2000 and 2001. Evaluation of recombinant protein and plasmid DNA scrub typhus vaccine candidates in a chigger challenge mouse model is under way [104].

First Lieutenant (1LT) Bailey K. Ashford proved in 1899 that Ancyclostoma duodenale, a species of hookworm, was a key cause of anemia in Puerto Rico. His discovery led to global therapeutic campaigns [26] and eventually to current hookworm vaccine efforts (a Phase 1 trial conducted by the George Washington University Medical Center in Washington, DC is under way [105]).

\section{Other ongoing U.S. DoD-related vaccine efforts}

Vaccines to protect against malaria, dengue, bacteriacaused diarrhea, hemorrhagic fever with renal syndrome, and human immunodeficiency virus (HIV) are in technology base development (managed by the Military Infectious Diseases Research Program [MIDRP]).

Development of vaccines to prevent and treat $P$. falciparum malaria (which may cause acute potentially fatal disease in persons without hard-won immunity acquired from recurrent exposure to malaria) and $P$. vivax malaria (most common cause of relapsing disease) is a U.S. military priority for several reasons. Infection transmitted by female Anopheles mosquitoes can render military personnel unable to fight and cause life-threatening disease. Insect repellents, bednets, and antimalarial drugs do not guarantee protection and may have adverse effects resulting in noncompliance. Troops may develop malaria after leaving malarious areas because of inadequate prophylaxis or poor prophylaxis compliance. Mosquitoes capable of transmitting malaria exist in the United States, and returning infected troops can transmit the disease to others. Malaria had a major impact in the Spanish-American War, the Pacific and India-Burma-China theaters in World War II, and the Vietnam War. Malaria also afflicted troops in the Korean War, Operation Restore Hope in Somalia [106], and 2003 operations in Liberia [107]. The U.S. military has co-developed with GlaxoSmithKline Biologicals a vaccine candidate referred to as RTS,S; trials intended to lead to licensure of this vaccine for prevention of severe malaria in children have commenced [108]. The U.S. military is also currently evaluating alternative approaches (including other recombinant protein antigens, viral vectors, naked DNA, and attenuated sporozoites) to induce potent and longlasting immune responses against $P$. falciparum $[109,110]$.

In 1906, U.S. Army officers CPT P.M. Ashburn and 1LT Charles F. Craig - sent to the Philippines to study dengue fever (DF) - discovered that DF is caused by a nonfilterable blood-transmitted agent involving neither protozoa nor bacteria [111]. Dengue viruses have a single-stranded RNA genome and belong to the genus Flavivirus (as do the causative agents of yellow fever, Japanese encephalitis, and West Nile fever). There are four distinct serotypes. Dengue virus infection (transmitted by Aedes aegypti, A. albopictus, and $A$. polynesiensis mosquitoes) may cause an acute painful febrile illness characterized by headache, muscle/joint pain, and rash requiring inpatient supportive care. Although this illness is rarely fatal in adults, dengue is a major cause of impaired troop readiness. Dengue epidemics adversely impacted U.S. military operations during the PhilippineAmerican War, World War II, Vietnam, Somalia, and Haiti. At present, dengue is an expanding health problem in the tropics and subtropics both in urban and rural areas, and there have been recent outbreaks in Texas and Hawaii. MIDRP efforts are focused on the development of a preventive vaccine using a variety of strategies (live attenuated vaccines, purified inactivated vaccines, and nucleic acid vaccines) rather than antiviral treatments for acute infection. Because dengue hemorrhagic fever - a more severe dengue illness - is associated with a second dengue infection with a different serotype, a tetravalent vaccine that protects against all four serotypes of dengue is ultimately needed [112].

Current U.S. military efforts in prevention of enteric infections are focused on development of vaccines for the major causes of diarrhea encountered by deployed U.S. military personnel-enterotoxigenic E. coli or ETEC (common on a global basis and also the major cause of travelers' diarrhea in civilians), Campylobacter jejuni (common particularly in Asia), and Shigella (especially Shigella flexneri and S. son$n e i$, common particularly in the Middle East during combat phases of deployment). Over half of U.S. service members deployed to the Middle East experience diarrhea due to occasional compromised hygiene, despite a strong emphasis on food and water sanitation by military health authorities. ETEC is the most common cause of diarrhea in U.S. forces deploying to many parts of the less developed world and can cause acute secretory diarrhea, which can result in patient incapacitation and dehydration.

Shigella are small Gram-negative rod-shaped bacteria that can cause infections associated with fever and bloody diarrhea. The infectious dose is small (10-1000 organisms); pathogenicity is related to propensity of tissue invasion, but the organism rarely penetrates beyond the mucosa and rarely causes bacteremia. Because most isolates of Shigella are resistant to multiple antimicrobials, successful drug treatment of Shigella infections is likely to become an increasing challenge. 
C. jejuni is a microaerophilic Gram-negative rod-shaped bacterium (closely related to Helicobacter pylori). Patients infected with Campylobacter most commonly present with fever, diarrhea (watery or bloody), and abdominal pain. The disease can be severe, but is generally self-limiting with rare relapses; it is occasionally associated with reactive arthritis and/or Guillain-Barre syndrome. Treatment of $C$. jejuni infections, particularly in Southeast Asia, is complicated by quinolone resistance (noted via stool isolates taken during joint Thai-U.S. military exercises). The mechanism by which Campylobacter causes disease is unclear. Development of a safe and reliable human challenge model is under way [113].

Potentially fatal hantaviral infections are transmitted to humans via aerosols of excreta originating from persistently infected rodents and have impacted U.S. military personnel deployed to Korea and the former Yugoslavia. Four distinct hantaviruses cause hemorrhagic fever with renal syndrome (HFRS): Hantaan virus (found primarily in Asia), Seoul virus (Asia, Europe, and Scandinavia), Dobrava virus (Balkan countries and western Russia), and Puumala virus (Scandinavia, Western Europe, and western Russia). Intravenous ribavirin has been shown to reduce mortality risk of HFRS only when given early in infection. No FDA-licensed vaccines are currently available to prevent this infection, and the DoD is sponsoring the only known attempt to develop a vaccine for HFRS in the United States [114]. Newly emerging hantaviruses that cause potentially fatal hantavirus pulmonary syndrome (HPS) in the Americas are also a concern. Hantavirus research performed by the U.S. military could result in medical countermeasures against both HFRS and HPS.

More than 300 new HIV infections occur annually in U.S. forces (including new recruits). Service members are at increased risk of infection when deployed to areas with high HIV prevalence; the primary risk for deployment-associated HIV infection is heterosexual encounters. Additionally, widespread HIV infection in some developing countries could increase the likelihood of political and financial instability, which could eventually necessitate peacekeeping intervention by U.S. military forces. In the mid-1980s, the U.S. Congress formally recognized the unique threat posed by HIV and acquired immunodeficiency syndrome (AIDS) to the operational effectiveness of U.S. military forces, directing the DoD to establish an HIV/AIDS research program. In 2002, Congress directed MIDRP to cooperate with NIH via the Division of AIDS at the National Institute of Allergy and Infectious Diseases (previously focused on B clade infections found principally within the United States) in the development of a globally effective HIV/AIDS vaccine for U.S. and allied forces protection. The lack of proven success with traditional antibody-mediated approaches using recombinant HIV envelope proteins and the pandemic nature of HIV justifies the utilization of a variety of other vaccine approaches including the use of modified vaccinia Ankara vectors, naked DNA vaccines, and multiclade immunogens.
Aggressive global HIV-1 surveillance and active prevention programs for the U.S. military and allied militaries around the world complement vaccine development efforts. The molecular epidemiology of endemic infections is utilized in vaccine design $[115,116]$.

Vaccines for endemic infectious diseases are important to global health in addition to the health of the U.S. Armed Forces. Furthermore, the U.S. military has stationed uniformed scientists in the tropics for more than 100 years and in active overseas laboratories for as long as six decades. Although development of vaccines is a priority, development of antimalarial drugs, diagnostic methods, and products to prevent transmission of diseases by vectors is also ongoing [117]. In addition, U.S. military scientists contribute to the development of health and science infrastructure in these tropical countries, which contributes to political stability.

\section{Acknowledgements}

The authors are grateful to DoD historians and current and past DoD research coordinators and scientists for their important contributions to this article, especially COL Donald G. Heppner, CAPT Kevin Porter, and Doctors Wendell Zollinger, Jay W. Hooper, Allen Richards, Maryanne Vahey, and Malabi M. Venkatesan. Thanks to COL (ret.) Bruce Innis for a careful reading of a draft manuscript of this paper.

Conflict of interest statement: The authors do not have a commercial or other association that might pose a conflict of interest. Funding: This work was supported by funding from the U.S. Army Medical Research and Materiel Command.

\section{References}

[1] Pittman M. The regulation of biologic products, 1902-1972. In: Greenwald HR, Harden VA, editors. National Institute of Allergy and Infectious Diseases: intramural contributions, 1887-1987. Bethesda, MD: National Institute of Allergy and Infectious Diseases; 1987. p. 61-70. Available at: http://www.history.nih.gov/articles/ NIAID_Intramural_Contributions.pdf (accessed April 8, 2007).

[2] Center for Biologics Evaluation and Research. Science and the regulation of biological products: from a rich history to a challenging future. Rockville, MD: Food and Drug Administration; 2002. Available in three parts at: http://www.fda.gov/cber/inside/cberbkp1.pdf, http://www.fda.gov/cber/inside/cberbkp2.pdf, and http://www.fda. gov/cber/inside/cberbkp3.pdf (accessed April 8, 2007).

[3] Barry JM. The great influenza: the epic story of the deadliest plague in history. New York: Viking; 2004.

[4] Crosby AW. Epidemic and peace, 1918. Westport, CT: Greenwood Press; 1976.

[5] Woodward TE, editor. The Armed Forces Epidemiological Board: the histories of the commissions. Washington, DC: Office of the Surgeon General, Department of the Army; 1994. Available at: http://history.amedd.army.mil/booksdocs/historiesofcomsn/default.htm (accessed September 28, 2006).

[6] Francis Jr T, Salk JE, Pearson HE, Brown PN. Protective effect of vaccination against induced influenza A. J Clin Invest 1945;24(4):536-46. 
[7] Salk JE, Pearson HE, Brown PN, Francis Jr T. Protective effect of vaccination against induced influenza B. J Clin Invest 1945;24(4):547-53.

[8] Salk JE, Menke Jr WJ, Francis Jr T. A clinical, epidemiological and immunological evaluation of vaccination against epidemic influenza. Am J Epidemiol 1945;42(1):57-93.

[9] Francis Jr T. Vaccination against influenza. Bull World Health Organ 1953;8(5-6):725-41.

[10] McNinch JH, Mason RP. The role of military medical services in future epidemic influenza. Am Rev Respir Dis 1961;83(2):198-200.

[11] Gaydos JC, Hodder RA, Top Jr FH, Soden VJ, Allen RG, Bartley JD, et al. Swine influenza A at Fort Dix, New Jersey (January-February 1976). I. Case finding and clinical study of cases. J Infect Dis 1977;136(Suppl):S356-62.

[12] Gaydos JC, Hodder RA, Top Jr FH, Allen RG, Soden VJ, Nowosiwsky T, et al. Swine influenza A at Fort Dix, New Jersey (January-February 1976). II. Transmission and morbidity in units with cases. J Infect Dis 1977;136(Suppl):S363-8.

[13] Hodder RA, Gaydos JC, Allen RG, Top Jr FH, Nowosiwsky T, Russell PK. Swine influenza A at Fort Dix, New Jersey (January-February 1976). III. Extent of spread and duration of the outbreak. J Infect Dis 1977;136(Suppl):S369-75.

[14] Schonberger LB, Bregman DJ, Sullivan-Bolyai JZ, Keenlyside RA, Ziegler DW, Retailliau HF, et al. Guillain-Barre syndrome following vaccination in the National Influenza Immunization Program, United States, 1976-1977. Am J Epidemiol 1979;110(2):105-23.

[15] Roscelli JD, Bass JW, Pang L. Guillain-Barre syndrome and influenza vaccination in the US Army, 1980-1988. Am J Epidemiol 1991;133(9):952-5.

[16] Kaplan JE, Katona P, Hurwitz ES, Schonberger LB. Guillain-Barre syndrome in the United States, 1979-1980 and 1980-1981. Lack of an association with influenza vaccination. JAMA 1982;248(6):698700 .

[17] Ottolini MG, Burnett MW. History of U.S. military contributions to the study of respiratory infections. Mil Med 2005;170(4 Suppl):66-70.

[18] Meiklejohn G, Zajac RA, Evans ME. Influenza at Lowry Air Force Base in Denver, 1982-1986. J Infect Dis 1987;156(4):649-51.

[19] Meiklejohn G. Viral respiratory disease at Lowry Air Force Base in Denver, 1952-1982. J Infect Dis 1983;148(5):775-84.

[20] Meiklejohn G, Eickhoff TC, Graves P, I J. Antigenic drift and efficacy of influenza virus vaccines, 1976-1977. J Infect Dis 1978;138(5):618-24.

[21] Meiklejohn G, Eickhoff TC, Graves P. Antibody response of young adults to experimental influenza A/New Jersey/76 virus vaccines. J Infect Dis 1977;136(Suppl):S456-9.

[22] Hoke Jr CH, Hopkins JA, Meiklejohn G, Mostow SR. Comparison of several wild-type influenza viruses in the ferret tracheal organ culture system. Rev Infect Dis 1979;1(6):946-54.

[23] Gremillion DH, Meiklejohn G, Graves P, I J. Efficacy of single-dose influenza in Air Force recruits. J Infect Dis 1983;147(6):1099.

[24] Hirsch MS. Measles, mumps, rubella, parvovirus, and poxvirus. In: ACP medicine. New York: WebMD; 2006.

[25] Grabenstein JD. ImmunoFacts: vaccines and immunologic drugs. St. Louis, MO: Wolters Kluwer Health, Inc.; 2005.

[26] Artenstein AW, Opal JM, Opal SM, Tramont EC, Peter G, Russell PK. History of U.S. military contributions to the study of vaccines against infectious diseases. Mil Med 2005;170(4 Suppl):3-11.

[27] Centers for Disease Control and Prevention. Elimination of rubella and congenital rubella syndrome, United States, 1969-2004. MMWR 2005;54(11):279-82

[28] Sivan A, Lee T, Binn L, Gaydos J. Where's adeno? A search for the occurrence of adenovirus-associated respiratory disease outside of the U.S. military. In: Presented at the International Conference on Emerging Infectious Diseases. 2006.

[29] Hilleman MR, Werner JH. Recovery of new agent from patients with acute respiratory illness. Proc Soc Exp Biol Med 1954;85(1):183-8.
[30] Hilleman MR, Werner JH, Dascomb HE, Butler RL, Stewart MT. Epidemiology of RI(RI-67) group respiratory virus infections in recruit populations. Am J Hyg 1955;62(1):29-42.

[31] Anonymous. Appraisal of studies in the light of subsequent knowledge of etiology of the acute viral respiratory diseases. Am Rev Respir Dis 1968;97(6 Pt 2):34-65.

[32] Dingle JH, Langmuir AD. Epidemiology of acute, respiratory disease in military recruits. Am Rev Respir Dis 1968;97(6 Suppl):1-65.

[33] Gaydos CA, Gaydos JC. Adenovirus vaccines. In: Plotkin SA, Orenstein WA, editors. Vaccines. 4th ed. Philadelphia: Saunders; 2004. p. 863-85.

[34] Chanock RM, Ludwig W, Heubner RJ, Cate TR, Chu LW. Immunization by selective infections with type 4 adenovirus grown in human diploid tissue cultures. I. Safety and lack of oncogenicity and tests for potency in volunteers. JAMA 1966;195(6):445-52.

[35] Edmondson WP, Purcell RH, Gundelfinger BF, Love JW, Ludwig W, Chanock RM. Immunization by selective infection with type 4 adenovirus grown in human diploid tissue culture. II. Specific protective effect against epidemic disease. JAMA 1966;195(6):453-9.

[36] Top Jr FH, Grossman RA, Bartelloni PJ, Segal HE, Dudding BA, Russell PK, et al. Immunization with live types 7 and 4 adenovirus vaccines. I. Safety, infectivity, antigenicity, and potency of adenovirus type 7 vaccines in humans. J Infect Dis 1971;124(2):148-54.

[37] Top Jr FH, Buescher EL, Bancroft WH, Russell PK. Immunization with live types 7 and 4 adenovirus vaccines. II. Antibody response and protective effect against acute respiratory disease due to adenovirus type 7. J Infect Dis 1971;124(2):155-60.

[38] Gray GC, Callahan JD, Hawksworth AW, Fisher CA, Gaydos JC. Respiratory diseases among U.S. military personnel: countering emerging threats. Emerg Infect Dis 1999;5(3):379-85.

[39] Gray GC, Goswami PR, Malasig MD, Hawksworth AW, Trump DH Ryan MA, et al. Adult adenovirus infections: loss of orphaned vaccines precipitates military respiratory disease epidemics. Clin Infect Dis 2000;31(3):663-70.

[40] Marrazzo JM. Infections due to Neisseria. In: ACP Medicine. New York: WebMD; 2006.

[41] Alexander CE, Sanborn WR, Cherriere G, Crocker Jr WH, Ewald PE, Kay CR. Sulfadiazine-resistant group A Neisseria meningitidis. Science 1968;161(845):1019.

[42] Goldschneider I, Gotschlich EC, Artenstein MS. Human immunity to the meningococcus. I. The role of humoral antibodies. J Exp Med 1969;129(6):1307-26.

[43] Goldschneider I, Gotschlich EC, Artenstein MS. Human immunity to the meningococcus. II. Development of natural immunity. J Exp Med 1969;129(6):1327-48.

[44] Gotschlich EC, Liu TY, Artenstein MS. Human immunity to the meningococcus. III. Preparation and immunochemical properties of the group A, group B, and group $\mathrm{C}$ meningococcal polysaccharides. J Exp Med 1969;129(6):1349-65.

[45] Gotschlich EC, Goldschneider I, Artenstein MS. Human immunity to the meningococcus. IV. Immunogenicity of group A and group $\mathrm{C}$ meningococcal polysaccharides in human volunteers. J Exp Med 1969;129(6):1367-84.

[46] Gotschlich EC, Goldschneider I, Artenstein MS. Human immunity to the meningococcus. V. The effect of immunization with meningococcal group $\mathrm{C}$ polysaccharide on the carrier state. J Exp Med 1969;129(6):1385-95.

[47] Artenstein MS, Gold R, Zimmerly JG, Wyle FA, Schneider H, Harkins C. Prevention of meningococcal disease by group $\mathrm{C}$ polysaccharide vaccine. N Engl J Med 1970;282(8):417-20.

[48] Gold R, Artenstein MS. Meningococcal infections. 2. Field trial of group C meningococcal polysaccharide vaccine in 1969-1970. Bull World Health Organ 1971;45(3):279-82.

[49] Griffiss JM, Brandt BL, Altieri PL, Pier GB, Berman SL. Safety and immunogenicity of group Y and group W135 meningococcal capsular polysaccharide vaccines in adults. Infect Immun 1981;34(3):72532. 
[50] Griffiss JM, Brandt BL, Broud DD. Human immune response to various doses of group $\mathrm{Y}$ and W135 meningococcal polysaccharide vaccines. Infect Immun 1982;37(1):205-8.

[51] Armand J, Arminjon F, Mynard MC, Lafaix C. Tetravalent meningococcal polysaccharide vaccine groups A, C, Y, W 135: clinical and serological evaluation. J Biol Stand 1982;10(4):335-9.

[52] Hankins WA, Gwaltney Jr JM, Hendley JO, Farquhar JD, Samuelson JS. Clinical and serological evaluation of a meningococcal polysaccharide vaccine groups A, C, Y, and W135. Proc Soc Exp Biol Med 1982;169(1):54-7.

[53] Brundage JF, Ryan MA, Feighner BH, Erdtmann FJ. Meningococcal disease among United States military service members in relation to routine uses of vaccines with different serogroup-specific components, 1964-1998. Clin Infect Dis 2002;35(11):1376-81.

[54] Brundage JF, Zollinger WD. Evolution of meningococcal disease epidemiology in the U.S. Army. In: Vedros NA, editor. Evolution of meningococcal disease, vol. 1. Boca Raton: CRC Press; 1987. p. 5-25.

[55] U.S. Food and Drug Administration. Meningococcal polysaccharide (serogroups A, C, Y and W-135) diphtheria toxoid conjugate vaccine (Menactra) [product approval information, licensing action]. Available at: http://www.fda.gov/cber/products/mpdtave011405.htm (accessed October 6, 2006).

[56] Leake JAD, Perkins BA. Meningococcal disease: challenges in prevention and management. Infect Med 2000;17(5):364-77.

[57] Boslego J, Garcia J, Cruz C, Zollinger W, Brandt B, Ruiz S, et al. Efficacy, safety, and immunogenicity of a meningococcal group B (15:P1.3) outer membrane protein vaccine in Iquique, Chile. Vaccine 1995;13(9):821-9.

[58] Drabick JJ, Brandt BL, Moran EE, Saunders NB, Shoemaker DR, Zollinger WD. Safety and immunogenicity testing of an intranasal group B meningococcal native outer membrane vesicle vaccine in healthy volunteers. Vaccine 1999;18(1-2):160-72.

[59] Fisseha M, Chen P, Brandt B, Kijek T, Moran E, Zollinger W. Characterization of native outer membrane vesicles from lpxL mutan strains of Neisseria meningitidis for use in parenteral vaccination. Infect Immun 2005;73(7):4070-80.

[60] Sawyer WA, Meyer KF, Eaton MD, Bauer JH, Putnam P, Schwentker FF. Jaundice in Army personnel in the western region of the United States and its relation to vaccination against yellow fever. Part I. Am J Epidemiol 1944;39(3):337-430.

[61] Sawyer WA, Meyer KF, Eaton MD, Bauer JH, Putnam P, Schwentker FF. Jaundice in Army personnel in the western region of the United States and its relation to vaccination against yellow fever. Parts II-IV. Am J Epidemiol 1944;40(1):35-107.

[62] Findlay GM, Martin NH. Jaundice following yellow fever immunisation: transmission by intranasal instillation. Lancet 1943;1(244):678-80.

[63] Hargett MV, Burruss HW, Donovan A. Aqueous-base yellow fever vaccine. Pub Health Rep 1943;58:505-12.

[64] Blumberg BS. Hepatitis B: the hunt for a killer virus. Princeton: Princeton University Press; 2002.

[65] Dooley DP. History of U.S. military contributions to the study of viral hepatitis. Mil Med 2005;170(4 Suppl):71-6.

[66] Szmuness W, Stevens CE, Zang EA, Harley EJ, Kellner A. A controlled clinical trial of the efficacy of the hepatitis B vaccine (Heptavax B): a final report. Hepatology 1981;1(5):377-85.

[67] Bancroft WH, Mundon FK, Russell PK. Detection of additional antigenic determinants of hepatitis B antigen. J Immunol 1972;109(4):842-8.

[68] Bancroft WH, Snitbhan R, Scott RM, Tingpalapong M, Watson WT, Tanticharoenyos $\mathrm{P}$, et al. Transmission of hepatitis $\mathrm{B}$ virus to gibbons by exposure to human saliva containing hepatitis B surface antigen. J Infect Dis 1977;135(1):79-85.

[69] Cirillo VJ. Bullets and Bacilli: the Spanish-American War and military medicine. New Brunswick, NJ: Rutgers University Press; 2004.

[70] Bollet AJ. Civil war medicine: challenges and triumphs. Tucson: Galen Press; 2002. p. 257-81.
[71] Russell FF. Antityphoid inoculation. Am J Med Sci 1913;146:803-33.

[72] Hardy A. "Straight back to barbarism": antityphoid inoculation and the Great War, 1914. Bull Hist Med 2000;74(2):265-90.

[73] U.S. Army Surgeon General's Office. The Medical Department of the United States Army in the World War, vol. IX: communicable and other diseases. Washington, DC: U.S. Government Printing Office; 1928. p. 15-60.

[74] U.S. Army Medical School. Immunization to typhoid fever: results obtained in the prevention of typhoid fever in the United States Army, United States Navy, and Civilian Conservation Corps, by the use of vaccines. Baltimore: Johns Hopkins Press; 1941.

[75] Levine MM, Ferreccio C, Black RE, Germanier R. Large-scale field trial of Ty21a live oral typhoid vaccine in enteric-coated capsule formulation. Lancet 1987;1(8541):1049-52.

[76] Black RE, Levine MM, Ferreccio C, Clements ML, Lanata C, Rooney J, et al. Efficacy of one or two doses of Ty21a Salmonella typhi vaccine in enteric-coated capsules in a controlled field trial. Vaccine 1990;8(1):81-4.

[77] Ferreccio C, Levine MM, Rodriguez H, Contreras R. Comparative efficacy of two, three, or four doses of TY21 a live oral typhoid vaccine in enteric-coated capsules: a field trial in an endemic area. J Infect Dis 1989;159(4):766-9.

[78] Simanjuntak CH, Paleologo FP, Punjabi NH, Darmowigoto R, Soeprawoto, Totosudirjo H, et al. Oral immunisation against typhoid fever in Indonesia with Ty21a vaccine. Lancet 1991;338(8774):10559.

[79] Woodward TE, Smadel JE, Ley Jr HL, Green R, Mankikar DS. Preliminary report on the beneficial effect of chloromycetin in the treatment of typhoid fever. Ann Intern Med 1948;29:131-4.

[80] Tribble D, Girgis N, Habib N, Butler T. Efficacy of azithromycin for typhoid fever. Clin Infect Dis 1995;21(4):1045-6.

[81] Wallace MR, Yousif AA, Mahroos GA, Mapes T, Threlfall EJ, Rowe B, et al. Ciprofloxacin versus ceftriaxone in the treatment of multiresistant typhoid fever. Eur J Clin Microbiol Infect Dis 1993;12(12):907-10.

[82] Frenck Jr RW, Nakhla I, Sultan Y, Bassily SB, Girgis YF, David J, et al. Azithromycin versus ceftriaxone for the treatment of uncomplicated typhoid fever in children. Clin Infect Dis 2000;31(5):11348.

[83] Girgis NI, Butler T, Frenck RW, Sultan Y, Brown FM, Tribble D, et al. Azithromycin versus ciprofloxacin for treatment of uncomplicated typhoid fever in a randomized trial in Egypt that included patients with multidrug resistance. Antimicrob Agents Chemother 1999;43(6):1441-4.

[84] Hoffman SL, Punjabi NH, Kumala S, Moechtar MA, Pulungsih SP, Rivai AR, et al. Reduction of mortality in chloramphenicol-treated severe typhoid fever by high-dose dexamethasone. N Engl J Med 1984;310(2):82-8.

[85] Lim ML, Murphy GS, Calloway M, Tribble D. History of U.S. military contributions to the study of diarrheal diseases. Mil Med 2005;170(4 Suppl):30-8.

[86] Vaughn DW, Hoke Jr CH. The epidemiology of Japanese encephalitis: prospects for prevention. Epidemiol Rev 1992;14:197-221.

[87] Buescher EL, Scherer WF. The ecology of Japanese encephalitis virus in Japan. Proceedings of the sixth international congresses on tropical medicine and malaria, vol. V. An Inst Med Trop (Lisb) 1959;16(Suppl 9):126-31.

[88] Defraites RF, Gambel JM, Hoke Jr CH, Sanchez JL, Withers BG, Karabatsos N, et al. Japanese encephalitis vaccine (inactivated, BIKEN) in U.S. soldiers: immunogenicity and safety of vaccine administered in two dosing regimens. Am J Trop Med Hyg 1999;61(2):288-93.

[89] Hoke Jr CH. History of U.S. military contributions to the study of viral encephalitis. Mil Med 2005;170(4 Suppl):92-105.

[90] Hoke CH, Nisalak A, Sangawhipa N, Jatanasen S, Laorakapongse T, Innis BL, et al. Protection against Japanese encephalitis by inactivated vaccines. N Engl J Med 1988;319(10):608-14. 
[91] Sanchez JL, Hoke CH, McCown J, DeFraites RF, Takafuji ET, Diniega BM, et al. Further experience with Japanese encephalitis vaccine. Lancet 1990;335(8695):972-3.

[92] Burke DS, Nisalak A. Detection of Japanese encephalitis virus immunoglobulin $\mathrm{M}$ antibodies in serum by antibody capture radioimmunoassay. J Clin Microbiol 1982;15(3):353-61.

[93] Gambel JM, DeFraites R, Hoke Jr C, Brown A, Sanchez J, Karabatsos $\mathrm{N}$, et al. Japanese encephalitis vaccine: persistence of antibody up to 3 years after a three-dose primary series. J Infect Dis 1995;171(4):1074.

[94] Bollet AJ. Civil war medicine: challenges and triumphs. Tucson: Galen Press; 2002. p. 283-306.

[95] Gellis SS, Stokes Jr J, Brother GM, Hall WH, Gilmore HR, Beyer $\mathrm{E}$, et al. The use of human immune serum globulin (gamma globulin) in infectious (epidemic) hepatitis in the Mediterranean theater of operations. I. Studies on prophylaxis in two epidemics of infectious hepatitis. JAMA 1945;128:1062-3.

[96] Anonymous. Prophylactic gamma globulin for prevention of endemic hepatitis. Effects of US gamma globulin upon the incidence of viral hepatitis and other infectious diseases in US soldiers abroad. Arch Intern Med 1971;128(5):723-38.

[97] Conrad ME, Lemon SM. Prevention of endemic icteric viral hepatitis by administration of immune serum gamma globulin. J Infect Dis 1987;156(1):56-63.

[98] Binn LN, Bancroft WH, Lemon SM, Marchwicki RH, LeDuc JW, Trahan CJ, et al. Preparation of a prototype inactivated hepatitis A virus vaccine from infected cell cultures. J Infect Dis 1986;153(4):74956.

[99] Sjogren MH, Hoke CH, Binn LN, Eckels KH, Dubois DR, Lyde L, et al. Immunogenicity of an inactivated hepatitis A vaccine. Ann Intern Med 1991;114(6):470-1.

[100] Hoke Jr CH, Binn LN, Egan JE, DeFraites RF, MacArthy PO, Innis BL, et al. Hepatitis A in the US Army: epidemiology and vaccine development. Vaccine 1992;10(Suppl 1):S75-9.

[101] Shrestha MP, Mrigendra P, Scott RM. Protection against hepatitis $\mathrm{E}$ by a recombinant vaccine. In: Presented at the American Society of Tropical Medicine and Hygiene 54th annual meeting. 2005.

[102] Harden VA. Rocky mountain spotted fever: history of a twentiethcentury disease. Baltimore: The Johns Hopkins University Press; 1990. p. 175-96.

[103] Medical Department, U.S. Army. Preventive medicine in World War II, vol. III: personal health measures and immunization. Washington, DC: Office of the Surgeon General, Department of the Army; 1955. p. 319-23.

[104] Chattopadhyay S, Jiang J, Chan TC, Manetz TS, Chao CC, Ching WM, et al. Scrub typhus vaccine candidate Kp r56 induces humoral and cellular immune responses in cynomolgus monkeys. Infect Immun 2005;73(8):5039-47.
[105] Sabin Vaccine Institute. Human Hookworm Vaccine Initiative (HHVI) overview. Available at: http://www.sabin.org/hookworm.htm (accessed October 11, 2006).

[106] Bwire R. Bugs in armor: a tale of malaria and soldiering. San Jose: iUniverse.com, Inc; 1999.

[107] Malaria outbreak among members of JTF Liberia: consensus conference report [October 9, 2003]. Available at: http://wwwnehc.med.navy.mil/downloads/prevmed/JTFMalaria.pdf (accessed October 11, 2006).

[108] Alonso PL, Sacarlal J, Aponte JJ, Leach A, Macete E, Aide P, et al. Duration of protection with RTS,S/AS02A malaria vaccine in prevention of Plasmodium falciparum disease in Mozambican children: single-blind extended follow-up of a randomised controlled trial. Lancet 2005;366(9502):2012-8.

[109] Heppner Jr DG, Kester KE, Ockenhouse CF, Tornieporth N, Ofori O, Lyon JA, et al. Towards an RTS,S-based, multi-stage, multi-antigen vaccine against falciparum malaria: progress at the Walter Reed Army Institute of Research. Vaccine 2005;23(17-8):2243-50.

[110] Ballou WR. Malaria vaccines in development. Expert Opin Emerg Drugs 2005;10(3):489-503.

[111] Gubler DJ. Commentary: Ashburn PM, Craig CF. Experimental investigations regarding the etiology of dengue $[\mathrm{J}$ Infect Dis 1907;4:440-75]. J Infect Dis 2004;189(9):1744-83. Available at: http://www.journals.uchicago.edu/JID/journal/issues/v189n9/32484/ 32484.web.pdf (accessed April 28, 2007)

[112] Sun W, Nisalak A, Gettayacamin M, Eckels KH, Putnak JR, Vaughn DW, et al. Protection of rhesus monkeys against dengue virus challenge after tetravalent live attenuated dengue virus vaccination. J Infect Dis 2006;193(12): 1658-65.

[113] Sanders JW, Putnam SD, Riddle MS, Tribble DR. Military importance of diarrhea: lessons from the Middle East. Curr Opin Gastroenterol 2005;21(1):9-14

[114] Hooper JW, Custer DM, Thompson E, Schmaljohn CS. DNA vaccination with the Hantaan virus $M$ gene protects hamsters against three of four HFRS hantaviruses and elicits a high-titer neutralizing antibody response in rhesus monkeys. J Virol 2001;75(18):846977.

[115] Nitayaphan S, Pitisuttithum P, Karnasuta C, Eamsila C, de Souza M, Morgan P, et al. Safety and immunogenicity of an HIV subtype B and $\mathrm{E}$ prime-boost vaccine combination in HIV-negative Thai adults. J Infect Dis 2004;190(4):702-6.

[116] Duerr A, Wasserheit JN, Corey L. HIV vaccines: new frontiers in vaccine development. Clin Infect Dis 2006;43(4):500-11.

[117] Kitchen LW, Vaughn DW, Skillman DR. Role of US military research programs in the development of US Food and Drug Administrationapproved antimalarial drugs. Clin Infect Dis 2006;43(1):6771. 